\title{
7
}

\section{Trade, SBTC and Skill Premia - A Cross-Country and Cross-Gender Analysis}

\author{
Oscar Afonso*, Alexandre Almeida and Cristina Santos \\ CEF.UP, Faculty of Economics, University of Porto, Porto \\ Portugal
}

\section{Introduction}

A recent study by Autor et al. (2008) has pointed out that the skill premia has risen in the US since the 60s. Several other authors have highlighted these trends across different OECD countries (e.g., Katz and Murphy, 1992; Machin, 1996; Goldin and Katz, 1999; Chay and Lee, 2000, Conte and Vivarelli, 2007). A common consensus points to the on-going growth of the demand for high-skilled workers, of which the Skill-Biased Technical Change (SBTC) and International Trade (IT) are the often cited sources.

According to the SBTC explanation, technology has evolved following a biased path towards more skilled workers. The bias makes technology complementary by nature to skilled workers and substitute of unskilled, hence expanding the relative productivity and demand for more educated workers (e.g, Bound and Johnson, 1992; Berman et al., 1994; Autor et al., 1998; Acemoglu, 1998; Berman et al., 1998; Galiani and Sanguinetti, 2003; Conte and Vivarelli, 2007). The IT explanation is based on the Stolper-Samuelson theorem's insights according to which IT would lead to the specialization of developed countries in more skill-intensive activities, thus raising the relative demand for skilled workers and the skill premia (e.g., Leamer, 1994; Sachs and Shatz, 1994; Wood, 1994; Feenstra and Hanson, 1996; Borjas et al., 1997; Leamer, 1998; Galiani and Sanguinetti, 2003; Gonzaga et al., 2006).

Even though the debate has been fierce and pending towards SBTC, literature on wage inequality has somewhat ignored how SBTC and IT impact on the skill premia across gender. In fact, even though several studies have suggested that SBTC fails to explain many aspects of the wage-structure changes, namely, the evolution of the skill premia across gender (e.g., Blau and Kahn,1997; Card and DiNardo, 2002; Acemoglu, 2003; Autor et al., 2008; Bryan and Martinez, 2008), empirical analysis are rare. The impact of IT on the gender-related wage inequality also remains unclear and has only been approached by a few authors (e.g., Seguino, 1997). Indeed, surveying empirical literature on the skill premia we observe that genderrelated skill premia differential has been subject to a minor attention with particular relevance in determining the universal character of SBTC as an explaining factor.

The goal of this chapter is to contribute to this issue empirically testing for 25 OECD countries how both SBTC and IT have affected the observed skill premia across gender. We

${ }^{*}$ Corresponding Author 
use two direct measures of the skill premia differential between male and female workers, namely, wage ratios per education level. Our estimation results indicate that SBTC conveys a dominant effect over the wage premium on the sample as a whole and for technological leaders, suggesting that in countries where technological intensive production activities are a small part, absorptive capacity may be limited and SBTC is actually not pervasive. IT has a smaller effect on the sample as a whole and for technological leaders; it is however the dominant for followers and always significant. In what concerns the gender-related inequality, we conclude that SBTC has also a strong and symmetric impact on the wage differential (positive on the club of leaders and negative on the club of followers). IT is again relatively less important in the wage gender-differential evolution.

We organized this chapter as follows: in section 2 we conduct our literature review, followed by the model's specification and methodological issues in section 3. Section 4 presents an analysis the estimated results. Section 5 concludes with some concluding remarks.

\section{Wage premium: Reviewing the empirical literature}

In this section we provide an overview on the empirical literature on the skill premia, focusing on empirical literature that has addressed the issue of gender inequality.

\section{Empirical literature review on the skill premia}

Empirical literature on the skill premia has usually debated which approach, SBTC or IT, was more appropriate in explaining the widening of the wage gap between skilled and unskilled workers. Our survey shows that few studies have considered both explanations together. Indeed, the majority of the empirical studies look only at one side of the debate, SBTC or IT.

In line with the Stolper-Samuelson theorem predictions, Wood (1994) concludes that IT contributes to an increase in the skill premia in the developed world and a decrease in the developing world. In a subsequent study, Sachs and Shatz (1996) concluded in the same direction of Wood (1994), finding a link between the increase in IT flows and the skill premia. Using aggregate data for the US manufacturing between 1972 and 1990, Feenstra and Hanson (1996) conclude that outsourcing, proxied by the imports of intermediate inputs contributed significantly to the relative increase in the demand for skilled labour. Leamer's (2001) results on the evolution of wages of productive and non productive workers in the $70 \mathrm{~s}$ and the $80 \mathrm{~s}$ in the US indicated that IT had a significant impact in the decline in the relative demand of unskilled labour and thus in the rise of the wage premium.

In an update study, Feenstra and Hanson (2003) estimate IT to be responsible for $15 \%$ to $24 \%$ of the wage-premium change and SBTC for $8 \%$ to $13 \%$. Also Green et al. (2001) identified a positive shift in the demand for skilled labour and in wage inequality in Brazil. However, Gonzaga et al. (2006) contradict the findings of Green et al. (2001). Recently there is a vibrant revived literature on IT and wage inequality, which reveals the increase in interest to the topic: e.g., Amiti and Konings (2007); Goldberg and Pavcnik (2007); Amity and Davis (2008); Broda and Romalis (2008); Helpman et al. (2008); Krugman (2008); Verhoogen (2008); Burstein and Vogel (2009); Egger and Kreickemeier (2009); Goldberg et al. (2008). In particular, the last two empirical studies provide strong evidence showing that imports of intermediates improve technological progress and thus productivity and wages in developing countries. 
The largest set of studies in the 90s has focussed on testing SBTC. One such example is Machin and Van Reenen (1998), who studied SBTC on 7 OECD countries finding evidence of a crucial association of R\&D intensity and the share in employment of skilled workers. Based on a sample of 12 OECD countries, Berman et al. (1998) concluded that there was a rise in the share of skilled workers across all countries, reinforcing the argument for SBTC's pervasive nature. The study by Katz and Autor (1999) also suggested that SBTC played a major role in explaining the wage-premium trend. Using a sample of 37 countries of different income levels, Berman and Machin (2000) obtained similar results. Studies like Goldin and Katz (1996), Bartel and Sicherman (1999), Kahn and Lim (1998) and Autor et al. (1998) study the US case and concluded in favour of the positive effect of SBTC on the skill premia.

Recently, Autor et al. (2003) estimated a within industry shift in favour of cognitive tasks linked to the increase in computer usage. This shift indicated that SBTC (proxied by computer usage) accounted for $60 \%$ of the wage inequality increase in the 70 s and the $80 \mathrm{~s}$.

The previous literature has provided evidence supporting SBTC's hypothesis. However, other authors have opposed these results, namely Card and DiNardo (2002). Arguing against the SBTC's holistic explanatory power, Card and DiNardo (2002) assessed the wage premium evolution across the US in the 80 s and 90s. They found that simultaneously to the expansion of computer usage, the wage skill differential remained stable which contradicts SBTC. Moreover, the authors highlight that SBTC provides no insights on a set of related issues such as the gender-wage gap. Also a recent study by Berman et al. (2005) on India's manufacturing sector devised for the period of 1983 to 1998 revealed inconclusive results regarding SBTC.

Furthermore, a small amount of studies analyze together how IT and SBTC account for the skill-premia evolution. One such study is Esquivel and Rodríguez-López (2003) who study how IT and SBTC impacted over the skill premia between 1988 and 2000; their results point to IT as the most relevant factor, but gender is nowhere mentioned. Manasse et al. (2004) in a study of the evolution of the skill premia in the Italian metal-mechanical industry suggest that IT and SBTC offset each other with SBTC stimulating an increase in wage inequality and IT a reduction. Again, how IT and SBTC impact on gender-based inequality is neglected and also occurs in Melka and Nayman (2004). In this last study, the authors make a comparative analysis of the skill premia in the US and France, concluding that ICT capital deepening and the R\&D stock promoted an increase in the demand of college graduates whereas IT seems to be not statistically relevant.

Using a multi-sector version of the Ricardo-Viner model of IT, Blum's (2008) results suggest that the sector bias rather than the skill bias nature of technological change is more relevant. Analysing the US skill premia trend from 1970 until 1996, Blum (2008) concludes that technology has been biased to more technology-intensive sectors.

The above mentioned studies have focussed on the skill-premia analysis disregarding issues of gender-based inequality apart from a reduced number of exceptions, namely Katz and Autor (1999), Card and DiNardo (2002) and Melka and Nayman (2004). Even among these studies, only Card and DiNardo (2002) analyze gender as more than a side question. Chusseau et al. (2008) extensive literature survey supports this conclusion, highlighting the poor attention devoted to how SBTC and/or IT impacted over gender-based wage 
inequality. Nevertheless, there is a small amount of studies combining skill premia and gender in the analysis. The next sub-section is devoted to a more close analysis of these.

\section{Empirical literature on the skill premia and gender}

Although Acemoglu (1998) stressed the importance of analysing the skill premia also in terms of gender inequality, not many studies have dealt with this issue, which is pointed as one of the possible flaws to the explaining power of the SBTC hypothesis. Nevertheless, even before Acemoglu (1998), Bound and Johnson (1992) analysed the path of wage differentials in the US, considering education levels and gender. Using data from CPS surveys reporting from 1973 to 1988, the authors' results indicate that the skill premia increased and gender inequality decreased during the $80 \mathrm{~s}$.

Presenting similar results, Card and DiNardo's (2002) study focuses on the path of wages and the wage structure in the US. In particular, they analyze how wage inequality and the skill premia has evolved across gender, race and age. Analysing the trends observed in the 80 s and the 90s, the authors highlight many inconsistencies or at least shortcomings of SBTC explanation. Card and DiNardo's (2002) empirical evidence point to a closing of the gender gap contradicting SBTC theory insights. According to the authors, the education gradient in computer use is higher for men than women and differences in computer use across gender are narrower for higher levels of education attainment. Finally, Card and DiNardo's (2002) evidence also point to a higher use of computers by male college graduates in relation to female ones. Hence, given SBTC's perspective based on computer use/skill complementarily, wage inequality should have widened in high levels of education and closed for the least educated. The SBTC's "rising skill price" perspective would suggest an expansion of inequality across all educational levels. Nevertheless, evidence is clear and the wage gap has overall narrowed by 15 percentual points (pp) between 1980 and 1992.

Arguing that computers replace workers performing routine cognitive tasks and manual tasks and that are complementary to workers performing non-routine tasks, Autor et al. (1998) tried to assess the pervasiveness of SBTC across different groups of analysis, including gender. For both men and women, the authors observe significant shifts of the relative demand for skilled workers, though considerably larger for women. However, Autor et al. (1998) do not analyze the impact on the wage premia, but the bigger shift of demand for skilled women may suggest that the gap should diminish at least for highly educated workers.

In general, there are not many empirical studies assessing how IT impacts on wage inequality (e.g., Anderson, 2005). There are even less that deal with gender-related issues. Among the exceptions, we find Seguino (1997) who concludes that the export-led growth of Korea had a small contribution to the narrowing of the gender wage gap. In the same line, Tzannatos (1999) analysis for 12 developing countries covering the 80s and the 90s go in the same direction of Seguino (1997) but estimating a bigger impact. Rama (2001) concludes that in Vietnam there was a significant reduction of the wage gap across gender in all educational levels during Vietnam's IT liberalization.

Galiani and Sanguinneti (2003) have analyzed Argentina's case. Focusing more clearly on the skill premia, they observe that the evolution across gender is actually similar, not addressing this issue from a pure gender gap perspective but providing results that indicate that the skill premia gender gap has increased with Argentina's liberalization. 
Oostendorp's (2004) findings suggest that IT and Foreign Direct Investment (FDI) net inflows reduced the gender gap among unskilled workers of developing countries.

In a recent study, Autor et al. (2008) focus on four inequality concepts: changes in overall wage inequality, changes in inequality in the upper and lower halves of the wage distribution, between-group wage differentials and within-group wage inequality. There results point to a narrowing of the gender-wage gaps since 1980.

Bryan and Martinez (2008) show that in the US the trends in male and female income inequality have been similar over the past few decades with interesting aspects, highlighting that the level of inequality seems to be lower among women than men, though increasing in both cases. Across gender, they conclude that inequality has been decreasing, with women's wages catching up with those of men, confirming Autor et al. (2008) results.

To sum up, there is a small number of studies combining the skill premia with gender. Most of them dealt do not focus in explaining asymmetries across gender, nor deal with it as a primary research issue. The surveys of Chusseau et al. (2008) on the gender-gap literature and of Brown and Campbell (2002) on the skill-premia literature highlight the scarce amount of analysis combining both approaches and which Acemoglu (1998) stated, may be an important contribution to the skill premia debate. Hence, we will focus our contribution on this matter, trying to assess how the skill premia evolved across gender, analyzing how IT and SBTC impacted on gender-based inequality.

\section{Modelling the case for gender wage premium}

In the previous section, we showed that empirical studies on the IT versus SBTC debate have neglected gender inequality. Our goal is to test if IT and/or SBTC explain a fall in gender asymmetries per level of education. On follower (developing) countries, IT may result in higher demand for less educated labour and this expansion lead to more equality. Moreover, since women are now the majority of college graduates, SBTC may have contributed to women fulfilling skilled-labour positions, thus reducing wage gaps towards men. On developed countries, wage-premium path across gender may also be explained SBTC, but IT, at least in Stolper-Samuelson theorem's sense, is probably an irrelevant explaining variable.

Based on a sample of 25 OECD countries and for a 10 year period (1997-2006), we estimate the effects of both IT and SBTC on wage-gender inequality. To test our hypothesis, we estimate the following model specification not only for the sample as a whole, but also for a sub-samples of countries defined for an R\&D threshold thus trying to stress the mentioned potential differences of kings for different kingdoms:

$$
W P_{i t}=\theta+\delta_{1} S B T C_{i t}+\delta_{2} I T+\varphi \mathrm{X}+v_{i t},
$$

where $i$ and $t$ stands for, respectively the country and year indexes. Moreover, according to our goal and model specification, our sample comprises proxies for the following variables: wage premium across gender, WP, skill-biased technical change, SBTC, International Trade, $I T$, and income level, GDP. To have statistical data coherence we used only OECD databases.

WP stands for wage premium and is our dependent variable. Since we are interested in capturing gender asymmetries and the effects of IT and SBTC, using the data retrieved from 
OECD's 2008 Education at Glance Report on the average wages earned by workers with superior, upper secondary and lower secondary education attainments and on wage inequality between men and women, we build skill-premium measures comparing earnings of colleges graduates with the ones of lower secondary graduates for male, $W P M_{s / \text {, female, }}$ $W P F_{s / \text {, }}$ and we will also use as a third dependent variable wage differential between man and woman per education levels superior, $W P M F_{s}$, and lower secondary, $W P M F_{l}$. This set of dependent variables present an advantage over the proxies mostly used in the literature that, usually due to data unavailability, use indirect measures of the skill premia to assess these relationships.

To evaluate the SBTC, several indicators have been used in the literature. For instance, Bartel and Sicherma (1999) used the proportion of scientists and engineers, Autor et al. (1998) used computer usage and Machin and Van Reenen (1998) use the share of R\&D expenditures on GDP. We will use this latter option for a set of reasons. It is available at OECD database for the entire period of our analysis and for all the 25 countries, it measures technology, being intimately associated to innovation performance and finally, it is highly correlated to computer usage thus capturing the majority of effects from ICT spread.

To proxy IT openness we follow Thoenig and Verdier (2002). Having retrieved data on imports, exports and GDP, we computed the degree of openness for each country and across time. The higher exposure to IT, should lead to an overall increase in the wage premium for OECD countries since they are relatively high-income countries but may have differentiated impact among them. If there asymmetries are relevant for this set of countries, then we would expect that IT would have a lower relative impact on the college premium on the higher income end of the sample whereas for the other pole, IT should aid reducing inequality.

To assess the existence of asymmetries across different stages of development, we estimate our model for a set of sub-samples resulting from the decomposition of the sample based on the stages of development. In particular, we decomposed the sample according to Castelacci and Archibugi (2008) technological clubs of convergence. They use an algorithm to cluster countries according to two composite factors: technological infra-structures and human capital and codified knowledge creation and diffusion. Their results identify clubs of convergence based on the countries technological capabilities and structural similarities, which, in our view, are particularly adequate to assess the potential asymmetries on the effects of IT and SBTC across countries with different potential technology absorption potential.

We also added a vector $X$, namely, the logarithm of GDP as a control variable.

Table 1 provides a brief statistical summary for the set of used dependent variables.

In particular, Table 1 shows that the wage premium on females is superior in relation to men's when considering wage inequality between college graduates and lower secondary per gender. When comparing the gender wage differential on college worker and on lower secondary workers, it is also observable that the level of gender discrimination is higher on the lower education levels. Some of these issues are further explored on the next section.

Similarly, Tables 2, 3 and 4 summarize statistic analysis for each explaining variable. We just highlight the inclusion of a measure of the annual variability of each explain variable, which will weigh each estimated coefficient thus giving us a more accurate estimated impact. 


\begin{tabular}{|ccccc|}
\hline Variable & Max & Min & Average & Std Deviation \\
\hline$W P M_{u / l}$ & 3.453 & 0.934 & 1.957 & 0.478 \\
\hline$W P F_{u / l}$ & 3.600 & 1.367 & 2.074 & 0.489 \\
\hline$W P M F_{u}$ & 2.732 & 0.884 & 1.51 & 0.244 \\
\hline$W P M F_{l}$ & 2.364 & 1.051 & 1.64 & 0.281 \\
\hline$W P_{u / l}$ & 5.18 & 0.95 & 1.97 & 0.51 \\
\hline
\end{tabular}

Statistical Source: OECD Science and Technology Indicators.

Table 1. Statistical summary of the variables used in the model's estimation.

\begin{tabular}{|cccccc|}
\hline Variable: SBTC & Max & Min & Average & Std Deviation & $\overline{\Delta S B T C}$ \\
\hline Full Sample & 4.77 & 0.49 & 1.90 & 0.96 & $0.03 \mathrm{pp}$ \\
\hline Leaders & 4.77 & 0.99 & 2.35 & 0.81 & $0.03 \mathrm{pp}$ \\
\hline Followers & 1.47 & 0.29 & 0.92 & 0.25 & $0.02 \mathrm{pp}$ \\
\hline
\end{tabular}

Statistical Source: OECD Science and Technology Indicators.

Table 2. Statistical Summary on SBTC - proxied by the annual share of R\&D expenditures on GDP.

\begin{tabular}{|cccccc|}
\hline Variable: IT & Max & Min & Average & Std Deviation & $\overline{\Delta T R A D E}$ \\
\hline Full Sample & 164.10 & 13.88 & 47.72 & 26.54 & $1.47 \mathrm{pp}$ \\
\hline Leaders & 164.10 & 14.84 & 51.83 & 26.98 & $1.24 \mathrm{pp}$ \\
\hline Followers & 100.74 & 13.88 & 39.50 & 23.73 & $1.55 \mathrm{pp}$ \\
\hline
\end{tabular}

Statistical Source: OECD Science and Technology Indicators.

Table 3. Statistical Summary on International Trade - proxied by the degree of openness.

\begin{tabular}{|cccccc|}
\hline Variable: LnGDP & Max & Min & Average & Std Deviation & $\overline{\Delta L n G D P}$ \\
\hline Full Sample & 16.39 & 11.15 & 12.96 & 1.14 & 0.05 \\
\hline Leaders & 16.39 & 11.15 & 13.07 & 1.23 & 0.05 \\
\hline Followers & 14.36 & 11.31 & 12.73 & 0.89 & 0.05 \\
\hline
\end{tabular}

Statistical Source: OECD.

Table 4. Statistical Summary on LnGDP.

To control for differences in structural characteristics, we use Castellaci and Archibuggi's (2008) clubs of convergence which splits our sample into leaders and followers in technological terms. Table 5 indicates the composition of each different clubs. 


\begin{tabular}{|l|l|}
\hline \multicolumn{1}{|c|}{ Full Sample (N=25) } & \multicolumn{1}{c|}{ All countries } \\
\hline $\begin{array}{l}\text { Technology Convergence } \\
\text { Club: Leaders (N=17) }\end{array}$ & $\begin{array}{l}\text { Australia, Austria, Belgium, Canada, Denmark, Finland, } \\
\text { France, Germany, Korea, Netherlands, New Zealand, } \\
\text { Norway, Sweden, Switzerland, United Kingdom, United } \\
\text { States, Israel. }\end{array}$ \\
\hline $\begin{array}{l}\text { Technology Convergence } \\
\text { Club: Followers (N=8) }\end{array}$ & $\begin{array}{l}\text { Czech Republic, Hungary, Ireland, Italy, Poland, Portugal, } \\
\text { Spain, Turkey. }\end{array}$ \\
\hline
\end{tabular}

Table 5. Composition of each sample group.

\section{Cross country evidence on the explanatory degree of SBTC and International Trade}

In this section we present and analyze the estimation results. In particular, we analyze in what way the two main explanations for the increase in wage inequality per education attainment, SBTC and IT, have in fact promoted the skill premia across gender and how they have impacted in gender-based inequality in both high and low level of education attainment. Next we analyze the estimates derived per each dependent variable and Table 6 presents our model estimation results assessing the evolution of the skill premia on male and female workers.

\begin{tabular}{|l|c|c|c|c|c|c|}
\hline \multirow{2}{*}{ Variables } & \multicolumn{4}{|c|}{$W P M_{u / l}$} & \multicolumn{3}{c|}{$W P F_{u / l}$} \\
\cline { 2 - 7 } & all & leaders & followers & all & leaders & followers \\
\hline SBTC & $0.26200^{* * *}$ & $0.30194^{* * *}$ & -0.11271 & $0.29136^{* * *}$ & $0.29516^{* * *}$ & -0.15598 \\
\hline Weighed effect & $0.00786^{* * *}$ & $0.00906^{* * *}$ & -0.00236 & $0.00874^{* * *}$ & $0.00885^{* * *}$ & -0.00312 \\
\hline IT & $0,00283^{* *}$ & $0.00382^{* * *}$ & $-0.00989^{* * *}$ & $0.00330^{* * *}$ & $0.00312^{* * *}$ & $0.00411^{* * *}$ \\
\hline Weighed effect & $0.00416^{* *}$ & $0.00474^{* * *}$ & $-0.01533^{* * *}$ & $0.00485^{* * *}$ & $0.00387^{* * *}$ & $0.00637^{* * *}$ \\
\hline LnGDP & -0.00911 & 0.05793 & $-0.35607^{* * *}$ & $-0.14123^{* * *}$ & 0.03627 & $-0.25405^{* * *}$ \\
\hline Constant & --- & --- & $7.28898^{* * *}$ & --- & -- & $5.63096^{* * *}$ \\
\hline NT & 250 & 170 & 80 & 250 & 170 & 80 \\
\hline Adjusted R & 0.934 & 0.879 & 0.328 & 0.95633 & 0.934 & 0.960 \\
\hline Method & FEM & FEM & Pool OLS & FEM & FEM & REM \\
\hline
\end{tabular}

Notes: ***Significant at $1 \%,{ }^{* *}$ significant at $5 \%,{ }^{*}$ significant at $10 \%$; Effects: Group only (G) or Group and Time (G\&T). Following Wooldridge (2002), we use the global significance F-test, the LagrangeMultiplier (LM) test and the Hausman test to choose which model (pool OLS, FEM or REM) is more suitable for our estimation in each case.

Table 6. Panel data estimation results of wage premium on male and female individuals.

When using the full sample and the club of convergence of more technology advanced countries, both the marginal and weighted effect of SBTC is dominant and positive, hence promoting an increase in the wage premium for both men and women. Nevertheless, it is statistically not significant for follower countries. For the full sample, SBTC has an estimated marginal effect of 26.2 pp over the wage premium of men and of 29.1 pp over the women's. Since the SBTC proxy scale of annual variability, the computed weighted effect amounts to 
$0.8 \mathrm{pp}$ and $0.9 \mathrm{pp}$ for men and women, respectively. For technologically advanced countries ("leaders"), the results are slightly higher on both male and female workers.

IT is also estimated to increase the wage premium for the full sample and the leaders group. However, the marginal effect is quite small and the weighted effect is about half the one estimated for SBTC. For the overall sample, the weighted effect is estimated to be $0.4 \mathrm{pp}$ on men and $0.5 \mathrm{pp}$ on women, slightly increasing for men in the leaders group and decreasing for women. However, despite SBTC dominance in the full sample and the leaders' group, for the set of countries classified as technological followers, SBTC is estimated to be not significant both for men and women. Here IT impact, both in marginal and weighted terms is dominant and higher than the registered for the other two samples. IT accounts for a marginal decrease in inequality estimated in about $-9.9 \mathrm{pp}$ for men but a positive of $4.1 \mathrm{pp}$ for women. In weighted terms, these values would reach -15.3 pp and $6.4 \mathrm{pp}$, respectively.

LnGDP is significant on followers and for both genders, accounting for a decrease in inequality estimated, in marginal terms, in $-0.36 \mathrm{pp}$ for men and $-0.25 \mathrm{pp}$ for women. The evidence supporting the impact of income in decreasing inequality is also present for the full sample, but only for women.

Thus, SBTC is dominant on the sample as a whole and for leaders, suggesting that in countries where technological intensive production activities are a small part, absorptive capacity may be limited and SBTC is actually not pervasive. Though IT has a smaller effect on the first two sets of countries, it is dominant for followers and always significant, in spite of symmetrical. In follower countries, IT contributes to a reduction of the wage premium of males but for an increase in inequality on females. LnGDP is only relevant and inequality reducing on follower countries. In terms of impact, GDP leaps seem to promote a higher inequality which we believe may be explained by the predominance of low-tech industries which, in line with Stolper-Samuelson, suffering an expansion from increased openness and low tech specialization, pushes outwards the demand for less skilled workers and hence contributes to the diminishing of the wage premium, in line with the estimations.

Literature has also questioned how SBTC and IT impacted on gender-based inequality (e.g. Acemoglu, 1998). The skill premia between male and female workers is quite significant (see Table 1), with men earning on average more from $51 \%$ to $64 \%$ more than women with the same education attainment. In here, we attempt to understand if for workers with the same competences (college or lower secondary), the observed gender related wage inequality increases or decreases with SBTC or IT. Hence, we re-estimated our model using the wage ratio of men to women for college educated workers and also for workers with less than a lower secondary degree. Results are synthesized in Table 7.

Analyzing the results on the gender-based wage inequality among college educated workers, the SBTC is the dominant factor in explaining the evolution observed. It is estimated to have a positive marginal impact of $16.4 \mathrm{pp}$ and a weighted impact of $0.49 \mathrm{pp}$ in leaders. In followers, our results indicate a symmetric effect with SBTC actually contributing to a decrease in the wage inequality between genders. This decrease amounts to $-61.1 \mathrm{pp}$ in marginal terms and a variability weighted effect of $-1.2 \mathrm{pp}$. However, SBTC is not significant for the sample as a whole, probably be due to the profound symmetries estimated between leaders and followers. These results suggest that SBTC has a biased impact not only across workers skills, but also across genders and the technological development stage of countries. 


\begin{tabular}{|l|c|c|c|c|c|c|}
\hline \multirow{2}{*}{ variables } & \multicolumn{3}{|c|}{ WPMF $_{u}$} & \multicolumn{3}{c|}{ WPMF $_{l}$} \\
\cline { 2 - 7 } & all & leaders & followers & all & leaders & followers \\
\hline SBTC & -0.00565 & $0.16399^{* * *}$ & $-0.61125^{* *}$ & $0.14806^{* *}$ & $0.17238^{* * *}$ & -0.11079 \\
\hline Weighed effect & -0.00017 & $0.00492^{* * *}$ & $-0.01223^{* *}$ & $0.00444^{* *}$ & $0.00517^{* * *}$ & -0.00222 \\
\hline IT & $-0.0131^{* * *}$ & $0.00125^{* *}$ & -0.00542 & 0.00045 & -0.00005 & $0.01008^{* * *}$ \\
\hline Weighed effect & $-0.01926^{* * *}$ & $0.00155^{* *}$ & -0.00840 & 0.00066 & 0.00006 & $0.015624^{* * *}$ \\
\hline LnGDP & $0.01957^{* *}$ & $-0.10323^{* * *}$ & 0.17204 & -0.08942 & $-0.15995^{* * *}$ & $0.11894^{* * *}$ \\
\hline Constant & 1.38517 & --- & --- & --- & -- & -0.28615 \\
\hline NT & 250 & 170 & 80 & 250 & 170 & 80 \\
\hline Adjusted R & 0.74 & 0.77 & 0.3 & 0.82 & 0.88 & 0.37 \\
\hline Method & Pool OLS & FEM & FEM & FEM & FEM & Pool OLS \\
\hline
\end{tabular}

Notes: see Table 6.

Table 7. Panel Data Estimation on gender based wage differential among college graduates and among lower secondary graduates.

IT is estimated to have a negative impact on the wage gap between male and female workers with college degree for the sample as a whole. In particular, our estimates indicate that IT has a marginal effect of $-1.3 \mathrm{pp}$ and a weighted effect of $-2.0 \mathrm{pp}$. IT is also a relevant explaining factor for the set of leaders. For these countries, however, the impact of IT is estimated to widen inequality, with a positive, though small, effect of $0.1 \mathrm{pp}$ and a weighted effect of $1.6 \mathrm{pp}$. In the club of convergence grouping the less technologically advanced countries, IT is estimated to have a negative impact but not statistically significant.

An interesting result arises from our control variable, LnGDP. LnGDP is not significant for follower countries. However, it is estimated to have a positive impact for the sample as a whole and a negative one in leaders. Not only this result seems to indicate that among the most advanced countries, the most gender egalitarian societies have a relatively lower GDP, but it may also become a dominant factor in a context of strong economic growth.

In sum, SBTC is also a predominant explanation for wage inequality widening across genders within college educated workers, conveying a symmetric effect (positive on leaders and negative on followers). IT is a less important determinant of wage inequality however, for college graduates and the sample as a whole, being not statistically significant for followers whereas GDP may become a dominant factor in a context of strong economic growth, contributing to the diminishing of inequalities between gender.

The second set of estimates on Table 7 redoes the above analysis for a set of workers with an educational attainment equal or below lower secondary degrees. Similarly to the results for the set of workers with college degrees, SBTC arises as the dominant explanation except for followers. For the full sample, SBTC accounts for an estimated marginal effect of $14.8 \mathrm{pp}$ and a weighted effect of $0.44 \mathrm{pp}$. These estimates are slightly higher when we re-estimated the model for the set of leaders. However, despite SBTC's dominance for these groups of countries, in followers our results indicate no statistical significance in spite of indicating also a negative effect upon gender inequality.

Unlike the estimates for workers with a college degree, now IT is only significant for the set of followers where in fact it contributes to an increase in inequality. Here, an increase in the 
openness level of the economy in $1 \mathrm{pp}$ would result in an increase in the wage differential between men and women of approximately $1 \mathrm{pp}$ in marginal terms.

The symmetric effect of the GDP level on gender-inequality is again present and following the already noticed path in the first set of estimates of Table 7. In particular, the GDP level has an inequality reducing impact on leaders and a widening impact on followers.

In sum, there seems to be a very relevant association of the pervasiveness of SBTC and a country technological development, having SBTC a dominant impact on these countries. Nevertheless, SBTC's effect is apparently symmetrical, contributing to the widening of the wage gap both within gender and across genders on technologically more advanced countries but to a an inequality reduction on less technologically advanced countries.

In what concerns IT, among college graduate workers, the overall effect is small but inequality reducing, signal that is common to the followers' sub-sample. For leaders, IT widens the gender wage gap. When assessing the impact of IT and SBTC hypothesis on the gender wage discrimination among lower skilled workers, SBTC seems to convey a positive impact both on the sample as a whole and on leaders, thus increasing wage inequality not education based. On followers, despite of being statistically insignificant, the sign is negative, as it was observed for college graduate workers. In terms of the fecundity of IT in explaining wage inequality between men and women, IT is only relevant for followers where it contributes positively to the wage differential between genders.

GDP has an inequality reducing effect on the wage premium and also on the wage differential per gender apart from the case of the full sample in college educated workers and followers for the group of less educated workers.

\section{Conclusions}

Literature has long been debating the reasons for the observed increase in the college wage premium focusing on theoretical arguments centered on two explanations, SBTC and IT. Our literature review highlighted the need to further empirical studies, namely assessing the SBTC and IT explanations impact on wages in a different perspective. Hence, we use SBTC and IT to assess based on a 25 OECD countries sample, possible asymmetries and the actual effects on the reduction or widening of gender inequality.

Using the traditional measure of wage premium and comparing differences between males and females, results show that SBTC is overall dominant, with IT, despite its smaller impact, being always significant and in a sense universal in explaining the skill premia.

SBTC's effect is symmetric across clubs of convergence and asymmetric in impact. In terms of signal, SBTC widens the wage premium and the gender differential for the full sample and leaders, apparently promoting a wage inequality decrease common to genders on followers (though, the latter effect is not statistically significant in all estimates). But the effects are also asymmetric in magnitude with SBTC accounting for a stronger impact on technologically more advanced countries, suggesting that the pervasiveness of technology is equal across distinct technological/economic country structural profile. SBTC is also a major explanation for wage inequality widening across genders within the same levels of education skill. Thus, SBTC has a biased impact not only across workers skills, but also across genders. 
IT is overall almost always statistically significant, conveying a higher impact over the set of technologically followers. IT estimated impact is lower than SBTC's however there is an interesting symmetric result that points to IT reducing the skill premia among men and widening it among women.

In sum, SBTC arises as the dominant explanation for the evolution of the wage premium within gender and the wage differential between genders, though the effects depend on the stage of development of a country. IT is estimated to convey a less powerful impact on wages although IT is more sample-universal.

\section{References}

Acemoglu, D. (1998). “Why do new technologies complement skills? Directed technical change and wage inequality." Quarterly Journal of Economics, vol. 113(4), pp. 1055-1089.

Acemoglu, D. (2003). "Patterns of skill premia." Review of Economic Studies, vol. 70(2), pp. 199-230.

Amiti, M. and Konings, J. (2007). "Trade liberalization, intermediate inputs and productivity: evidence from indonesia." American Economic Review, vol. 97(5), pp. 1611-1638.

Amiti, M. and Davis, D. (2008). "Trade, firms and wages: theory and evidence." NBER Working Papers No. 14106.

Anderson, E. (2005). "Openness and inequality in developing countries: a review of theory and recent evidence." World Development, vol. 33(7), pp. 1045-1063.

Autor, D., Katz, L. and Kearney, M. (2008). "Trends in U.S. wage inequality: revising the revisionists." Review of Economics and Statistics, vol. 90(2), pp. 300-323.

Autor, D., Katz, L. and Krueger, A. (1998). "Computing inequality: have computers changed the labour market?" Quarterly Journal of Economics, vol. 113(4), pp. 1169-1213.

Autor, D., Levy, F. and Murnane, R. (2003). "The skill content of recent technological change: an empirical exploration." Quarterly Journal of Economics, vol. 118(4), pp. 1279-1333.

Bartel, A. P. and Sicherman, N. (1999). "Technology change and wages: an inter-industry analysis." Journal of Political Economy, vol. 107(2), pp. 285-325.

Berman, E. and Machin, S. (2000). "Skill-biased technology transfer around the world." Oxford Review of Economic Policy, vol. 16(3), pp. 12-22.

Berman, E., Bound, J. and Griliches, Z. (1994). "Changes in the demand for skilled labour within U.S. manufacturing industries: evidence from the annual survey of manufacturing." Quarterly Journal of Economics, vol. 109(2), pp. 367-397.

Berman, E., Bound, J. and Machin, S. (1998). "Implications of skill-biased technological change: international evidence." Quarterly Journal of Economics, vol. 113(4), pp. 1245-1279.

Berman, E., Somanathan, R. and Hong, T. (2005). "Is skill-biased technological change here yet? Evidence from Indian manufacturing in the 1990." World Bank Policy Research Working Paper $\mathrm{N}^{\mathrm{o}} 3761$.

Blau, F. and Kahn, L. (1997). "Swimming upstream: Trends in the gender wage differential in the 1980s." Journal of Labor Economics, vol. 15(1), pp. 1-42.

Blum, B. (2008). "Trade, technology, and the rise of the service sector: the effects on US wage inequality." Journal of International Economics, vol. 74, pp. 441-458.

Borjas, G., Freeman, R., Katz, L., DiNardo, J. and Abowd, J. (1997). "How much do immigration and trade affect labor market out-comes?" Brookings Papers on Economic Activity, pp. 1-90. 
Bound, J. and Johnson, G. (1992). “Changes in the structure of wages in the 1980's: an evaluation of alternative explanations." American Economic Review, vol. 82(3), pp. 371-392.

Broda, C. and Romalis, J. (2008). "Inequality and prices: does China benefit the poor in America?" Working Paper, University of Chicago.

Brown, C. and Campbell, B. (2002). "The impact of technological change on work and wages." Industrial Relations, vol. 41(1), pp. 1-33.

Bryan, K. and Martinez, L. (2008). "On the evolution of income inequality in the United States." Economic Quarterly, vol. 94(2), pp. 97-120.

Burstein, A. and Vogel, J. (2009). "Globalization, technology, and the skill premium." working paper, UCLA.

Card, D. and DiNardo, J. (2002). “Skill-biased technological change and rising wage inequality: some problems and puzzles." Journal of labour Economics, vol. 20(4), pp. 733-783.

Castellacci, F. and Archibugi, D. (2008). "The technology clubs: The distribution of knowledge across nations." Research Policy, vol. 37(10), pp. 1659-1673.

Chay, K. and Lee, D. (2000). "Changes in relative wages in the 1980s: returns to observed and unobserved skills and black-white wage differentials." Journal of Econometrics, vol. 99(1), pp. 1-38.

Chusseau, N., Dumont, M. and Hellier, J. (2008). “Explaining rising inequality: skill-biased technical change and North-South trade." Journal of Economic Surveys, vol. 22(3), pp. 409-457.

Conte, A. and Vivarelli, M. (2007). "Globalization and employment: imported skill-biased technological change in developing countries." JENA Economic Research Papers, $\mathrm{n}^{\circ} 9$.

Egger, H. and Kreickemeier, U. (2009). "Firm heterogeneity and the labor market effects of trade liberalization." International Economic Review, vol. 50, pp. 187-216.

Esquivel, G. and Rodríguez-Lopes, J. (2003). “Technology, trade, and wage inequality in Mexico before and after NAFTA." Journal of Development Economics, vol. 72, pp. 543- 565.

Feenstra, R. and Hanson, G. (1996). "Globalization, outsourcing, and wage inequality." American Economic Review, vol. 86(2), pp. 240-245.

Feenstra, R. and Hanson, G. (2003). "Global production sharing and rising inequality: a survey of trade and wages.", in Handbook of International Trade, vol. 1, edited by E. Kwan Choi and James Harrigan, Malden, Mass.: Blackwell Publishing.

Galiani, S. and Sanguinetti, P. (2003). "The impact of trade liberalization on wage inequality: evidence from Argentina." Journal of Development Economics, vol. 72, pp. 497-513.

Goldberg, P. and Pavcnik, N. (2007). "Distributional effects of globalization in developing countries." Journal of Economic Literature, vol. 45, pp. 39-82.

Goldberg, P., Khandelwal, A., Pavcnik, N. and Topalova, P. (2008). “Imported intermediate inputs and domestic product growth: evidence from India." NBER Working Paper No. 14416.

Goldin, C. and Katz, L. (1996). “Technology, skill and the wage structure: insights from the past." American Economic Review, vol. 86(2), pp. 252-257.

Goldin, C. and Katz, L. (1999). "The returns to skill in the United States across the twentieth century." NBER Working Papers No. 7126.

Gonzaga, G., Filho, N. and Terra, C. (2006). "Trade liberalization and the evolution of skill earnings differentials in Brazil." Journal of International Economics, vol. 68(2), pp. 345-367.

Green, F., Dickerson, A. and Arbache, J. (2001). "A picture of wage inequality and the allocation of labor through a period of trade liberalization: the case of Brazil." World Development, vol. 29(11), pp. 1923-1939. 
Greiner, A., Rubart, J. and Semmler, W. (2004). "Economic growth, skill-biased technical change and wage inequality: a model and estimations for the US and Europe." Journal of Macroeconomics, vol. 26(4), pp. 597-621.

Helpman, E., Itskhoki, O. and Redding, S. (2008). “Wages, unemployment and inequality with heterogeneous firms and workers." NBER Working Papers No.14122.

Kahn, J. and Lim, J. (1998). "Skilled labor-augmenting technical progress in U.S. manufacturing." Quarterly Journal of Economics, vol. 113(4), pp. 1281-1308.

Katz, L. and Autor, D. (1999). "Changes in the wage structure and earnings inequality", in O. Ashenfelter and D. Card (eds.), Handbook of Labor Economics, vol. 3. Amsterdam: Elsevier-North Holland.

Katz, L., Murphy, K. (1992). “Changes in relative wages, 1963-1987: supply and demand factors." Quarterly Journal of Economics, vol. 107(1), pp. 35-78.

Krugman, P. (2008). "Trade and wages, reconsidered." Brookings Papers on Economic Activity, pp. 103-154.

Leamer, E. (1998). "In search of Stolper-Samuelson linkages between international trade and lower wages", in Collins, S. (Ed.), Imports, Exports and the American Worker, Brookings Institution, pp. 141-202.

Leamer, E. (2001). "In search of Stolper-Samuelson effects on U.S. wages." NBER Working Papers No 5427.

Leamer, Edward E. (1994). “Trade, wages and revolving door ideas.” NBER Working Papers No 4716.

Machin, S. and Van Reenen, J. (1998). “Technology and changes in skill structure: evidence from seven OECD countries." Quarterly Journal of Economics, vol. 113(4), pp. 1215-1244.

Machin, S. (1996). "Wage inequality in the UK." Oxford Review of Economic Policy, vol. 12(1), pp. 47-64.

Manasse, P., Stanca, L. and Turrini, A. (2004). “Wage premia and skill upgrading in Italy: why didn't the hound bark?" Labour Economics, vol. 11(1), pp. 59-83.

Melka, J. and Nayman, L. (2004). "Labour quality and skill biased technological change in France." Centre d'Études Prospectives e d'Informations Internationales.

Oostendorp, R. (2004). "Globalisation and the gender wage gap", World Bank Working Paper No 3256.

Rama, M. (2001). "The gender implications of public sector downsizing: The reform program of Vietnam." World Bank Working Paper No 2573.

Sachs, J. and Shatz, H. (1996). "US trade with developing countries and wage inequality." American Economic Review, vol. 86(2), pp. 234-239.

Seguino, S. (1997). "Gender wage inequality and export-led growth in South Korea." Journal of Development Studies, vol. 34(2), pp. 102-132.

Thoenig, M. and Verdier, T. (2003). "A theory of defensive skill biased innovation and globalization." American Economic Review, vol. 93(3), pp. 709-728.

Tzannatos, Z. (1999). "Women and labour market changes in the global economy: Growth helps, inequalities hurt and public policy matters." World Development, vol. 27(3), pp. 551-570.

Verhoogen, E. (2008). "Trade, quality upgrading and wage inequality in the Mexican manufacturing sector." Quarterly Journal of Economics, vol. 123, pp. 489-530.

Wood, A. (1994). North-South trade, employment and inequality. Oxford University Press.

Wooldridge, J. (2002). Econometric Analysis of Cross Section and Panel Data, Cambridge, MA: MIT Press. 


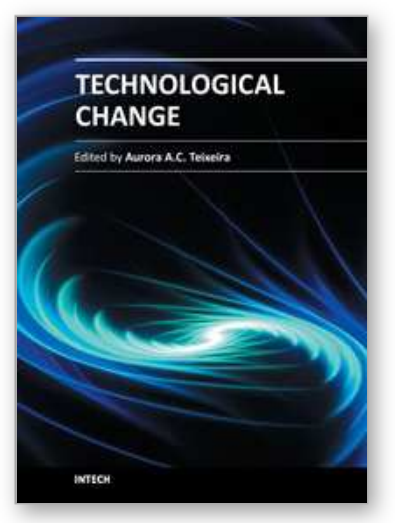

\author{
Technological Change \\ Edited by Dr. Aurora Teixeira
}

ISBN 978-953-51-0509-1

Hard cover, 238 pages

Publisher InTech

Published online 11, April, 2012

Published in print edition April, 2012

Technological change is today central to the theory of economic growth. It is recognised as an important driver of productivity growth and the emergence of new products from which consumers derive welfare. It depends not only on the work of scientists and engineers, but also on a wider range of economic and societal factors, including institutions such as intellectual property rights and corporate governance, the operation of markets, a range of governmental policies (science and technology policy, innovation policy, macroeconomic policy,competition policy, etc.), historical specificities, etc. Given that technology is explicitly taken up in the strategies and policies of governments and firms, and new actors both in the national and international arenas become involved, understanding the nature and dynamics of technology is on demand. I anticipate that this book will decisively contribute in this regard.

\title{
How to reference
}

In order to correctly reference this scholarly work, feel free to copy and paste the following:

Oscar Afonso, Alexandre Almeida and Cristina Santos (2012). Trade, SBTC and Skill Premia - A CrossCountry and Cross-Gender Analysis, Technological Change, Dr. Aurora Teixeira (Ed.), ISBN: 978-953-510509-1, InTech, Available from: http://www.intechopen.com/books/technological-change/trade-sbtc-and-skillpremia-a-cross-country-and-cross-gender-analysis

\section{INTECH}

open science | open minds

\author{
InTech Europe \\ University Campus STeP Ri \\ Slavka Krautzeka 83/A \\ 51000 Rijeka, Croatia \\ Phone: +385 (51) 770447 \\ Fax: +385 (51) 686166 \\ www.intechopen.com
}

\author{
InTech China \\ Unit 405, Office Block, Hotel Equatorial Shanghai \\ No.65, Yan An Road (West), Shanghai, 200040, China \\ 中国上海市延安西路65号上海国际贵都大饭店办公楼 405 单元 \\ Phone: +86-21-62489820 \\ Fax: $+86-21-62489821$
}


(C) 2012 The Author(s). Licensee IntechOpen. This is an open access article distributed under the terms of the Creative Commons Attribution 3.0 License, which permits unrestricted use, distribution, and reproduction in any medium, provided the original work is properly cited. 